Boletín de la Sociedad Geológica Mexicana

VOLUMEN 65, NÚM. 2, 2013, P. 355-368

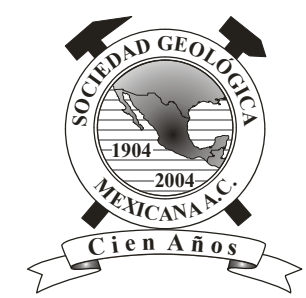

\title{
Revision of the fossil species of Goneplax Leach, 1814 (Crustacea, Decapoda, Brachyura, Goneplacidae)
}

\author{
Alessandro Garassino ${ }^{1, *}$, Giovanni Pasini ${ }^{2}$, Peter Castro ${ }^{3}$ \\ ${ }^{1}$ Museo di Storia Naturale, Sezione di Paleontologia, Corso Venezia 55, 20121 Milano, Italia. \\ ${ }^{2}$ Via Alessandro Volta 16, I-22070 Appiano Gentile (Como), Italia. \\ ${ }^{3}$ Biological Sciences Department, California State Polytechnic University, Pomona, California 91768-4032, USA. \\ *alegarassino@gmail.com
}

\begin{abstract}
A revision of the fossil species of Goneplax Leach, 1814, has resulted in the assignment of four fossil species to Goneplax, but only G. gulderi Bachmayer, 1953, and G. rhomboides are considered as valid. Goneplax craverii Crema, 1895, previously assigned to Retropluma Gill, 1894, G. formosa Ristori, 1886, and G. meneghinii Ristori, 1886, are regarded as junior synonyms of G. rhomboides, while G. sacci Crema, 1895, is considered a nomen dubium. Albaidaplax n. gen. is here erected to include both the Italian specimens from the Miocene of Rio Popogna (Livorno, Tuscany, Italy) and the Spanish specimens from the Pliocene of Guadalquivir Basin (Seville, Andalusia, Spain) previously assigned to G. gulderi. Finally, Ommatocarcinus arenicola Glaessner, 1960, from the Late Oligocene-Middle Miocene of New Zealand, is assigned to the extant Neogoneplax Castro, 2007, constituting the first report of this genus in the fossil record.
\end{abstract}

Keywords: Crustacea, Decapoda, Brachyura, Goneplacidae, Miocene, Pliocene, Italy, Austria, Spain, New Zealand.

\section{Resumen}

La revisión de las especies de Goneplax Leach, 1814, ha arrojado la asignación de cuatro especies fósiles de Goneplax, pero sólo G. gulderi Bachmayer, 1953, y G. rhomboides son consideradas como válidas. Goneplax craverii Crema, 1895, previamente asignada a Retropluma Gill, 1894, G. formosa Ristori, 1886, y G. meneghinii Ristori, 1886, son consideradas como sinónimos junior de G. rhomboides, mientras que G. sacci Crema, 1895, es considerada como nomen dubium. Se propone Albaidaplax $n$. gen. para incluir tanto los especímenes italianos del Mioceno de Rio Popogna (Livorno, Toscana, Italia) como los especímenes españoles del Plioceno de la Cuenca de Guadalquivir (Sevilla, Andalucía, España), previamente asignados a G. gulderi. Finalmente, se asigna Ommatocarcinus arenicola Glaessner, 1960, del Oligoceno Tardio-Mioceno Medio de Nueva Zelanda, al género existente Neogoneplax Castro, 2007, y constituye el primer registro del género como fósil.

Palabras Clave: Crustacea, Decapoda, Brachyura, Goneplacidae, Mioceno, Plioceno, Italia, Austria, España, Nueva Zelanda. 


\section{Introduction}

Castro (2007) reviewed the extant members of the subfamily Goneplacinae MacLeay, 1838, whereas Guinot and Castro (2007) pointed out the status of Goneplax rhomboides (Linnaeus, 1758) and Castro et al. (2010) gave a detailed table of diagnostic characters of the eleven goneplacoid families. Goneplax Leach, 1814, was revised to include the following fossil species previously listed by Karasawa and Kato (2003): G. arenicola (Glaessner, 1960), G. craverii Crema, 1895, G. formosa Ristori, 1886, G. meneghinii Ristori, 1886, G. gulderi Bachmayer, 1953, G. saccoi Crema, 1895, and the fossil and extant G. rhomboides (Linnaeus, 1758). Goneplax craverii had been previously assigned to Retropluma Gill, 1894 (Retroplumidae Gill, 1894) by Beschin et al. (1996) (see also De Angeli et al., 2011). New, well-preserved specimens from the Miocene and Pliocene of Italy nevertheless necessitate a revision of the fossil species of Goneplax. The main diagnostic characters used in this study have been considered regarding the status of preservation of the specimens, where only the carapace and some other parts of the exoskeleton are observable. On the other hand, the male and female gonopores, male pleopods (G1 and G2) and thoracic sternal sutures, which are important diagnostic structures useful in neontological systematics, are never or very rarely preserved in fossil crabs.

\subsection{Taphonomy and taxonomic remarks}

Several of the reviewed specimens are preserved more or less mineralized as internal moulds only, lacking the original exoskeleton due to the peculiar process during the fossilization which destroys the original cuticle or subsequently washes it. The specimens from some localities such as Albaida del Ajarife (Guadalquivir Basin, Seville, Spain), Monterotondo Marittimo, and Volterra (Tuscany, Italy) are especially preserved as internal moulds, rich in iron redox, as well as the specimen from New Zealand which is also a washed internal mould poorly preserved in a calcareous rock. This kind of preservation mislead some authors who confused the presence of a median frontal notch as an external character on the cuticle (Glaessner, 1960), while it can be interpreted as the imprint of an internal subrostral thickening structure. Therefore lacking the original dorsal ornamentation and the ventral parts, the main diagnostic characters considered to compare fossil and extant species in this study are limited to the general form of the carapace, the shape of the outer orbital tooth, the orbital outline, and the presence or absence of anterolateral teeth or knobs.

\section{Material}

This review includes all the specimens previously referred to Goneplax reported in the paleontological record, as well as additional unreported specimens recently discovered in Italy and Spain.

The material is deposited in the Centro Civico "Ofelia Mangini", seat of Gruppo GAMPS (Badia a Settimo, Scandicci, Florence, Italy) (CF-TCR); Geological Section of the Museo di Storia Naturale dell'Accademia dei Fisiocritici, Siena (MUSNAF); Gruppo Paleontologico “C. De Giuli”, Biblioteca Comunale Vallesiana (Castelfiorentino, Florence, Italy) (GPDG); Museo Geologico di Castell'Arquato (Piacenza, Italy) (MG); Museo Geológico, Universidad de Sevilla, Spain (MGUS); Museo Regionale di Scienze Naturali di Torino (PU); Museo di Storia Naturale dell'Università degli Studi di Firenze (IGF); Museo di Storia Naturale di Milano (MSNM); Naturhistorisches Musem, Wien (NHMW); New Zealand Geological Survey (GNS).

\section{Systematic Paleontology}

\section{Superfamily Goneplacoidea MacLeay, 1838 \\ Family Goneplacidae MacLeay, 1838 \\ Subfamily Goneplacinae MacLeay, 1838}

Key to the fossil genera Goneplax Leach, 1814, Albaidaplax n. gen., Neogoneplax Castro, 2007 (Goneplacinae MacLeay, 1838)

Carapace transversely rectangular to trapezoidal, strongly wider than long; widest at anterolateral tooth; dorsal surface of carapace smooth with raised horizontal ridges, without clear indication of regions; front slightly concave or straight, not marked by slight median notch or projection; front shorter than orbits; orbits wide, greatly expanded distally; supraorbital border conspicuously sinuous; outer orbital angle with conspicuous acute tooth; anterolateral margins diverging frontally or rounded with single acute tooth or knob; male cheliped (P1) elongated in some species: Goneplax.

Carapace transversely rectangular, slightly wider than long; dorsal surface of carapace smooth with slight horizontal ridges, without clear indication of regions; straight front slightly turned downwards; orbits wide, gently expanded distally; supraorbital border gently sinuous; outer orbital angle with short acute tooth; anterolateral margins slightly convex, with single short tooth; male cheliped (P1) short, with stout palm: Albaidaplax.

Carapace transversely rectangular, much wider than long; widest at conspicuous outer orbital tooth; dorsal surface of carapace smooth or with slight horizontal ridges, without clear indication of regions; straight front, slightly deflected ventrally; orbits wide, greatly expanded distally; supraorbital border conspicuously convex; outer orbital angle with conspicuous acute tooth; anterolateral margin with one single tooth (acute or obsolete); cheliped (P1) long, slender: Neogoneplax. 
Genus Goneplax Leach, 1814

Type species: Ocypoda bispinosa Lamarck, 1801 [= Goneplax rhomboides (Linnaeus, 1758)], by original designation.

Diagnosis (after Castro, 2007): Carapace transversely rectangular to trapezoidal, much wider than long; widest at anterolateral teeth posterior to conspicuous outer orbital teeth; front slightly deflected ventrally, slightly concave or straight, not marked by slight median notch or projection. Notch between front, inner edge of supraorbital border distinct, slight, or absent; orbits wide, greatly expanded distally; supraorbital borders conspicuously sinuous; suborbital borders sinuous, with slight, wide obtuse inner tooth not visible dorsally; anterolateral borders short, straight or slightly convex. Dorsal surface of carapace smooth, with slight horizontal ridges, moderately convex, without clear indication of regions. Outer orbital angle with conspicuous, acute tooth; single acute anterolateral tooth on each side of carapace (short, obtuse, or obsolete in some specimens of $G$. rhomboides). Basal antennal article short, distalmost (third) article reaches front. Eye peduncles long, shorter to as long as front (0.4-1.0 front width); cornea spherical to elongated. No obvious stridulating mechanism other than possible rubbing of proximal portion of cheliped (P1) merus against pterygostomial ridge. Thoracic sternum wide. Median line on thoracic sternite 4 absent; sutures $4 / 5,5 / 6,7 / 8$ interrupted medially, 6/7 complete. Anterior end of sterno-abdominal cavity anterior to thoracic sternite 4 . Cheliped fingers long, slender, straight or slightly curved, shorter than elongated propodus; variable portion of dactylus darker in colour, tip light; carpus with tooth on inner margin (absent in large individuals). Dorsal margins of ambulatory leg (P2-P5) meri with acute distal tooth; dactyli slender, with carina on each side, setose. Male pleon with 6 freely-movable somites plus telson, narrowly triangular, somites 4-6 gradually decreasing in width from somite 3 (widest somite). Telson slightly longer than wide. Somite 3 covers space between P5 coxae, somite 2 much narrower than somite 3 so that somites 1,2 leave relatively large portion of thoracic sternite 8 visible. G1 long, slender, thin, slightly sinuous, only slightly broadened proximally; pointed, thin tip. G2 slender, slightly longer or slightly shorter than G1, flagellum shorter than proximal part (peduncle), curved; slightly-expanded tip with 1 or 2 spinules. Penis arising from P5 coxa, moderate size; broad, soft proximal expansion. Female pleon with 6 freely-movable somites, wide. Telson much wider than long. Somite 3 covers space between P5 coxae, somite 2 slightly narrower than somite 3 but somites 1, 2 leave relatively large portion of thoracic sternite 8 visible. Vulva of mature females round, extending from oblique 5/6 suture to $6 / 7$ suture or to median portion of thoracic sternite 6 , covered by soft membrane, vulvar cover absent.
Key to the fossil species of Goneplax Leach, 1814

Carapace transversely subtrapezoidal or quadrate, slightly wider than long, widest at anterolateral tooth; carapace smooth, with two raised horizontal ridges, without clear indication of regions; front slightly concave, not marked by median notch or projection; front as wide as orbits; relatively wide orbits, slightly expanded distally; outer orbital angle with conspicuous acute tooth; anterolateral margins straight frontally; single reduced anterolateral tooth (short or acute); male cheliped (P1) short, with stout palm Goneplax gulderi.

Carapace transversely trapezoidal (more marked in male), strongly wider than long, widest at anterolateral tooth; carapace smooth, with two slight horizontal ridges, without clear indication of regions; front slightly concave, not marked by median notch or projection; front shorter than the orbits; wide orbits, greatly expanded distally; outer orbital angle with conspicuous acute tooth; anterolateral margins diverging frontally; single acute anterolateral tooth (short, acute, or obsolete); male cheliped (P1) well developed, with elongated palm Goneplax rhomboides.

\section{Goneplax gulderi Bachmayer, 1953}

Figure 1.A

Goneplax gulderi Bachmayer, 1953: 143, 144, pl. 9, figs. 1-3.

Goneplax gulderi - Müller, 1984: 96, pl. 93, figs. 2-3. Müller, 1993: 23, fig. 11 K. - Mayoral et al., 1998: 508, 509, fig. 2 (5). - Müller, 1998: 38. - Garassino and De Angeli, 2004: 45. - De Angeli and Garassino, 2006: 65. - Castro, 2007: 686. - De Angeli et al., 2009: 187, 188, 189, fig. 18 A, B. - Schweitzer et al., 2010: 135. - Garassino et al., 2012: 46. - Pasini and Garassino, 2013: 321, 322.

Goneplax cf. saccoi [sic] - Vía, 1948: 146, fig. 6. - Solé and Vía, 1989: 34.

Goneplax cf. gulderi - Müller, 1979: 6 .

Remark. Bachmayer (1953) described G. gulderi from one complete carapace, decorticated and poorly preserved, and from one isolated dactylus. De Angeli et al. (2009) subsequently referred some additional specimens from the Miocene of Tuscany to this species. Their state of preservation allows for the first time to point out the main diagnostic characters of G. gulderi.

Emended diagnosis: Carapace transversely subtrapezoidal or quadrate, slightly wider than long, widest at anterolateral tooth; front straight, not marked by median notch or projection; front as wide as orbits; relatively wide orbits, slightly expanded distally; outer orbital angle with triangular, conspicuous acute tooth; anterolateral margins straight frontally; single reduced anterolateral tooth (short or acute); posterolateral margins tapering posteriorly; straight posterior margin; smooth dorsal surface of carapace, with raised horizontal ridges, without clear indication of regions; male cheliped (P1) short; rounded carpus with anterolateral 

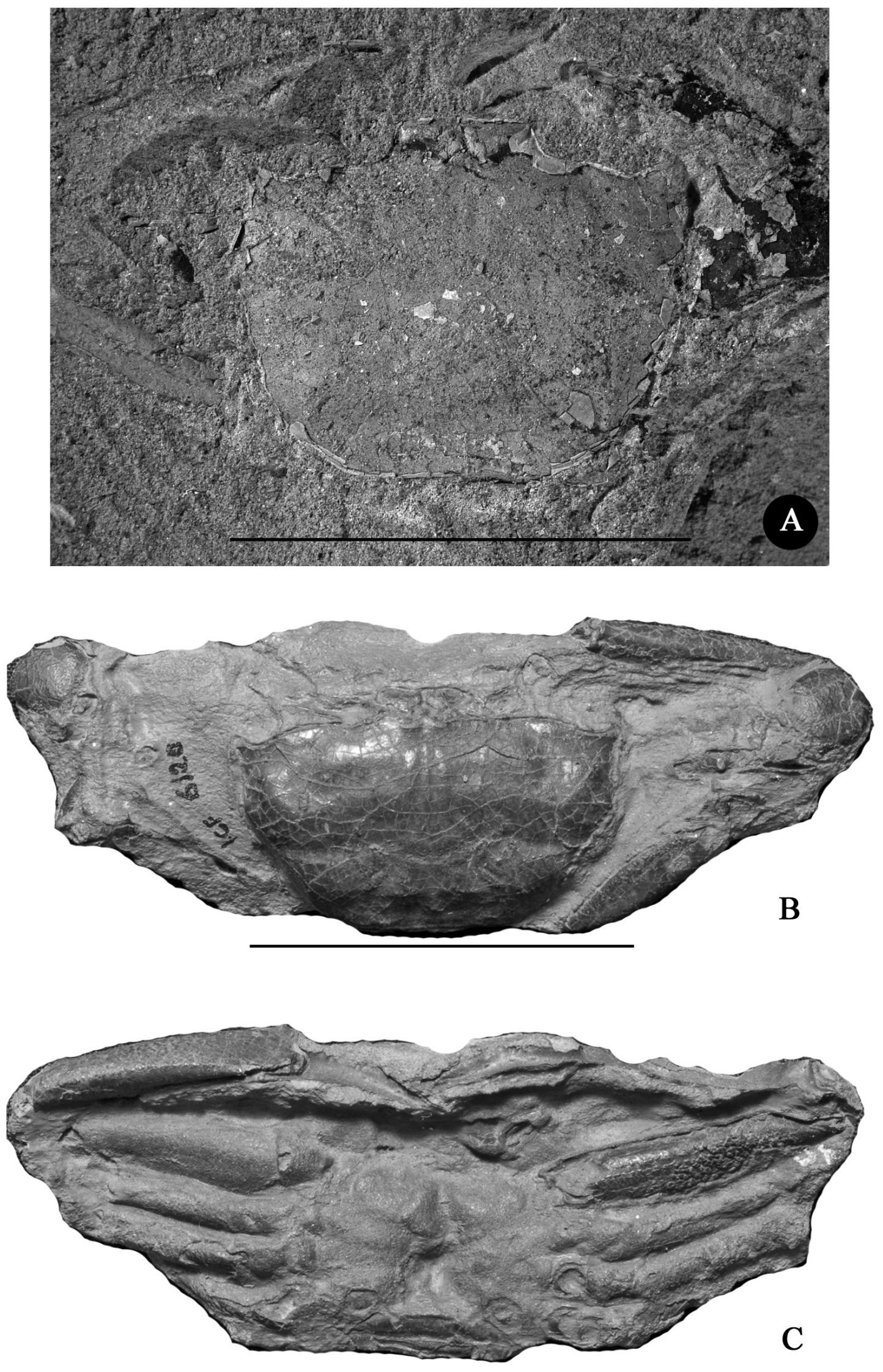

Figure 1. A, Goneplax gulderi Bachmayer, 1953, holotype NHMW 1953/0053/0001. Scale bar: $32 \mathrm{~mm}$. B, Goneplax formosa Ristori, 1886, holotype IGF 612E. A) dorsal view. Scale bar: $30 \mathrm{~mm}$. C) ventral view. Scale bar: $20 \mathrm{~mm}$. 
spine; stout palm; elongated, flat ambulatory legs (P2-P5).

Holotype: NHMW 1953/0053/0001.

Geological age: Miocene.

Occurrence: Austria (Baden); Italy (Tuscany).

Additional studied material: complete specimens in dorsal view (MSNM i27082, i27083, i27084, i27085, i27086, i27087; GPDG 0085, 0086, 0087, 0088); isolated dactylus (MHNW 1953/0053/0001b).

Description: We confirm the original description by Bachmayer (1953) and the updated data by Müller (1993).

Discussion: Bachmayer (1953) was unable to point out the main specific characters of his new species because of the decortication of the dorsal surface of the carapace. Goneplax gulderi differs from G. rhomboides in the presence of the two well-marked transverse ridges on the wider than long carapace and especially for the anterior margin where each orbit is as wide as the front. In G. rhomboides the orbits are indeed wider than the width of the front.

\section{Goneplax rhomboides (Linnaeus, 1758)}

Figures 1.B, 1.C, 2

Cancer rhomboides Linnaeus, 1758: 626.

Goneplax angulata Leach, 1814: 430.

Goneplax impressa Desmarest, 1817: 504, 505.

Goneplax rhomboides - Milne-Edwards, A., 1861: 88. Heller, 1863: 104, pl. 3, figs. 3, 4.- Ristori, 1886: 111-113. Vía, 1948: 146. - Bachmayer, 1953: 145. - Holthuis and Gottlieb, 1958: 99. - Zariquiey Álvarez, 1959: 5. - Holthuis, 1961: 57. - Zariquiey Álvarez, 1968: 414-416, fig. 138 a, b. - Rice and Chapman, 1971: 336, 337, 339, figs 5-7. Pastore, 1972: 108, 113. - Jenkins, 1975: 33, 57. - Garcia Raso, 1984: 108, 111. - Garcia Socias and Massuti Jaume, 1987: 81, 92. - Falciai and Minervini, 1992: 238, pl. 17, fig. 1. - Müller, 1993: 23. - d'Udekem d'Acoz, 2001: 49. Karasawa and Kato, 2003: Tab, 1, Tab. 6. - Vukanic, 2003: 150. - Garassino and De Angeli, 2004: 44, 45, figs. 12-15. - Garassino et al., 2004: 274, 275, fig. 14. - Company et al., 2004: 78. - De Angeli and Garassino, 2006: 65. Suat Ates et al., 2006: 134, 136, 138, 140. - Castro, 2007: 686-690, 692, fig. 27. - Celik et al., 2007: 183. - Fanelli et al., 2007: 22, 23, 25. - Ng et al., 2008: 80. - De Angeli et al., 2009: 188, 189. - Neumann et al., 2010: S27-S30, figs 2, 3. - Schweitzer et al., 2010: 135. - Capezzuto et al., 2010: 204. - Mura and Corda, 2011: 680. - Garassino et al., 2012: 45-47, 53, fig. 20 C, D. - Pasini and Garassino, 2013: 321,322 .

Goneplax romboides [sic] - Glaessner, 1929: 199. - Vía Boada, 1933: 226.

Goneplax cf. rhomboides - Gemmellaro, 1914: 90, pl. 1, fig. 26.

Gonoplax rhomboidea [sic] - Lörenthey, 1909: 250, 251.

Goneplax angulata - Heller, 1863: 103.- Nobre, 1936: 57; pl. 21, fig. 40. - Bouvier, 1940: 278, fig. 176; pl. 9, fig. 2. - Zariquiey Álvarez, 1946: 162, pl. 18, figs. a, b.

Gonoplax [sic] impressa-Desmarest, 1822: 102-104, pl. 8, figs. 13,14

Goneplax impressa - Garassino et al., 2012: 46.

Gonoplax [sic] bispinosa - Ristori, 1891: 20, 21.

Gonoplax [sic] formosa Ristori, 1886: 111-114, pl. 3, figs. 11-13. nov. syn.

Goneplax formosa - Glaessner, 1929: 198. - Castro, 2007: 686. - De Angeli et al., 2009: 188. - Schweitzer et al., 2010: 135. - Garassino et al., 2012: 46.

Gonoplax [sic] meneghinii Ristori, 1886: 114-116, pl. 3, figs. 8-10. nov. syn.

Gonoplax [sic] meneghinii-Ristori, 1891: 21. - Ristori, 1892: 89. - Ristori, 1896: 506.

Goneplax meneghinii - Lörenthey, 1909: 250, 251. Glaessner, 1929: 199. - Castro, 2007: 686. - De Angeli et al., 2009: 188. - Schweitzer et al., 2010: 135. - Garassino et al., 2012: 46.

Gonoflax [sic] meneghini? [sic] - Tettoni, 1924: 161.

Holotype: Most probably not extant (Castro, 2007: 688).

Geological age: Miocene - Pleistocene.

Occurrence: Italy (Piedmont, Emilia Romagna, Tuscany, Lazio, Sicily).

Additional studied material: G. rhomboides - complete specimens (GPDG 0137, 0138; IGF 100007; MG 0596, 0597, 0598, 0599, 0600, 0602, 0612, 0614, 0621; MSNM i27766; PU 41185, 41186); incomplete specimens (MSNM i27762, i27764, i27765); complete specimen in ventral view (CF-TCR 2) erroneously assigned by De Angeli et al. (2009) to G. gulderi; chelae (MG 0601, 0632, 0633); type material of $G$. formosa - holotype (IGF 612E); type material of $G$. meneghinii - syntypes (IGF 609E, 610E, 611E).

Remark: The incomplete specimen assigned to $G$. bispinosa by Ristori (1891) (Zuccari coll., Museo di Geologia e Paleontologia, Rome, Italy); the isolated dactylus assigned to $G$. cfr. rhomboides by Gemmellaro (1914) (Museo Geologico, Palermo, Sicily, Italy); and the specimen assigned to G. impressa by Desmarest (1817, 1822) (paleontological collection of Muséum national d'Histoire naturelle, Paris) are lost. Milne-Edwards, A. (1861) reported many carapaces from Monte Pellegrino (Palermo) without repositories.

Ristori (1896) assigned one specimen from the Pliocene of Pancoli (Limite, Valdarno) to Goneplax meneghinii, without repository; Tettoni (1924) assigned dubiously some specimens from the Pliocene of S. Venanzio (Modena) to Goneplax meneghini (Museo Geologico, Università di Modena, without catalogue numbers); the rich collection of decapods from S. Venanzio probably includes Tettoni's specimens; however it was impossible to recognise Tettoni's original specimens because of the lack of catalogue numbers and figured specimens (P. Serventi, pers. comm., 2012).

Discussion: Goneplax rhomboides (Linnaeus, 1758) is so far known only in the fossil record of Italy from the Miocene to Pleistocene of Piedmont, Emilia Romagna, Tuscany, Lazio, and Sicily, as reported by many authors (Desmarest, 1817, 1822; Milne-Edwards, A., 1861; Gemmellaro, 1914; Garassino and De Angeli, 2004; 

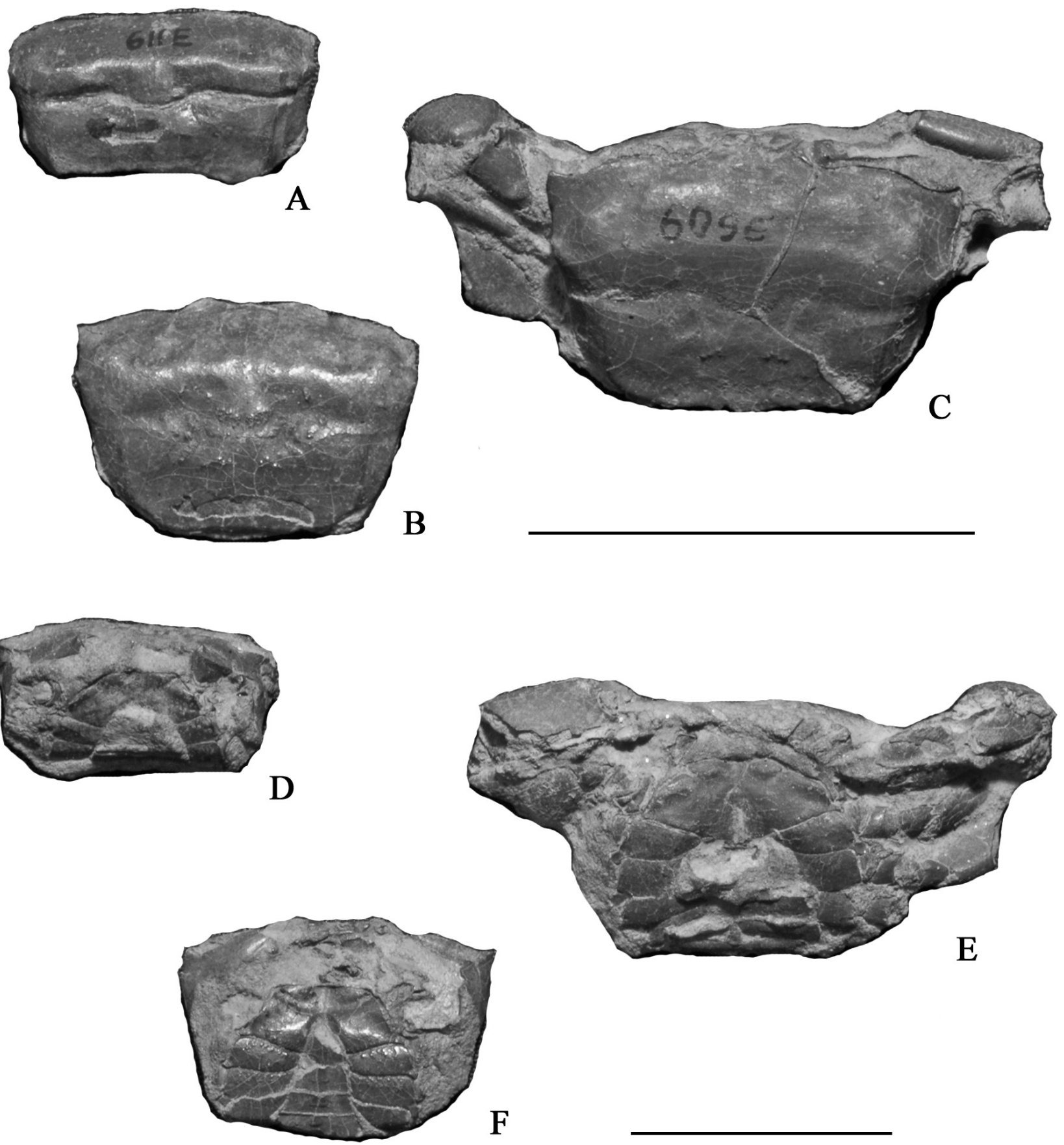

$\mathrm{F}$

Figure 2. Goneplax meneghinii Ristori, 1886, dorsal and ventral views of syntypes IGF 609E (A, D, female), 610E (B, F, male), 611E (C, E, female). Scale bars: $30 \mathrm{~mm}$

Garassino et al., 2004; Garassino et al., 2012; Pasini and Garassino, 2013). This species is widespread in the eastern Atlantic, western Africa, and Mediterranean Sea, burrowing in sublittoral shallow muddy and sandy bottoms from a few to about $100 \mathrm{~m}$ deep (Falciai and Minervini, 1992; Zariquiey Álvarez, 1968).

Ristori (1886: pl. 3; figs. 11, 12, 13) described G. formosa Ristori, 1886, from the Pliocene of Rapolano (Siena, Tuscany) by a single three-dimensionally preserved male carapace, with incomplete legs and right propodus. Ristori $(1886: 111,112)$ pointed out that the specimen was closer to G. rhomboides, but differed in having a marked trapezoidal carapace with orbito-frontal margin wider than the posterior margin; well-distinct regions, some small granulations on the cardiac lobe and orbital cavity (?different from G. rhomboides). Some measurements of the carapace were reported and compared with a carapace of an extant specimen of $G$. rhomboides to show the differences between 
the two species (Ristori, 1886: 111).

Müller (1993) subsequently marked that “...As it was pointed earlier, the carapace of the Mediterranean extant species G. rhomboides is extremely variable. Its range of variability most probably covers the two Pliocene Italian forms (G. formosa Ristori, 1886, and G. meneghini Ristori, $1886 \ldots)$.. Following Müller (1993), and based on the original description and comparison with the holotype of G. formosa, we consider as non-diagnostic the characters described by Ristori, due to the variability in the carapace shape and ornamentation in G. rhomboides. Therefore, $G$. formosa is here considered as junior synonym of $G$. rhomboides.

Ristori (1886: 112; pl. 3, figs. 8, 9, 9a, 10) described the main characters of $G$. meneghinii Ristori, 1886, from the Pliocene of Rapolano (Siena, Tuscany) using three carapaces (two females and one male), three-dimensionally preserved. Ristori (1886) pointed out that “...this species is more similar to the extant form ( $=$ G. rhomboides), than the previous one $(=G$. formosa) $\ldots$...'. Especially the females show some different characters: subquadrate carapace; wider front; more developed posterior margin; small sparse tubercles ranged along the cardiac lobes and the frontal margins. Other possible differences are described on the general distribution of the lobes and form of the ocular orbits. Also for this species still stand the remarks of Müller (1993), (see above in this discussion). We point out that the shape of the carapace observed by Ristori (1886) fits into variability of the extant females of G. rhomboides, where the form is generally less trapezoidal and more subquadrate due the shorter fronto-orbital margin and the wider posterior, as seen in the Adriatic Sea specimens. For these reasons, and following Müller (1993), we consider the characters described by Ristori (1886), as non-specific, including $G$. meneghinii as a junior synonym of $G$. rhomboides.

\section{Goneplax sacci Crema, 1895}

Figure 3

Goneplax [sic] sacci Crema, 1895: 674, 675, fig. 15.

Goneplax sacci - Lörenthey, 1909: 250, 251. - Müller, 1993: 23. - De Angeli and Garassino, 2006: 65. - De Angeli et al., 2009: 189. - Garassino et al., 2012: 4§, 47, fig. 20E.

Goneplax cf. sacci - Lörenthey, 1907: 94, pl. 3, figs. 4a-c, 6, 7; pl. 4, fig. 6. - Lörenthey, 1909: 249, pl. 1, figs. 4 a-c, 6-7, pl. 2, fig. 6. - Glaessner, 1928: 193, 194, fig. 7. - Bachmayer, 1953: 145. - Jenkins, 1975: 57.

Goneplax saccoi [sic] - Glaessner, 1929: 199, 200. Karasawa and Kato, 2003: Tab. 6. - Castro, 2007: 686. - Schweitzer et al., 2010: 135.

Holotype: PU (Rovasenda coll.) lost (D. Ormezzano, pers. comm., 2012).

Geological age: Early Pliocene (Zanclean).

Occurrence: Italy (Piedmont, Tuscany, Sardinia); Austria?

Remark: the specimens assigned to Goneplax cfr. sacci by Lörenthey $(1907,1909)$ from Capo S. Marco (Cagliari, Sardinia - Lovisato coll.) and by Glaessner (1928) from Tegel (Austria - Graz coll.) appear to be lost.

Discussion: Crema (1895) assigned one poorly preserved specimen from the Early Pliocene of Monte Capriolo (Bra, Turin, Piedmont, Italy) to Goneplax sacci Crema, 1895. The loss of the holotype questions the validity of this species. The perfunctory description and the poorly preserved specimen, as reported and figured by Crema (1895: fig. 15), do not permit to determine the peculiar diagnostic characters of the genus ("... subtrapezoidal to quadrate smooth carapace..., regions more marked than in G. rhomboides..., front wide less of $1 / 3$ of the total wideness with frontal margin straight and rounded lateral corners..., orbits less developed than in G. rhomboides..., anterolateral margins diverging posteriorly ..., postorbital and lateral spines broken...”). Moreover, as pointed out by Crema (1895: 675) the regions of the carapace are well distinct with well-marked transversal ridges, characters closer to both $G$. gulderi and retroplumids in which the regions of the carapace are always indistinct, having very weak transversal ridges. Although the holotype is lost, we could suppose that $G$. sacci belongs to Retropluma, as Goneplax craverii Crema, 1895 (= Retropluma craverii not Goneplax craverii as reported by Schweitzer et al., 2010) having distinct carapace regions and well-marked transversal ridges. Based on these observations, we consider G. sacci a nomen dubium.

In contrast to what was recently stated by some authors (De Angeli and Garassino, 2006; De Angeli et al., 2009; Schweitzer et al., 2010; Garassino et al., 2012), G. gulderi Bachmayer, 1953, must not be considered a synonym of G. sacci. These authors have erroneously followed Müller (1993: 23) who did not consider $G$. sacci a synonym of $G$. gulderi: "...The ill preserved type of G. sacci have [sic] a fronto-orbital margin similar to that of G. gulderi, but

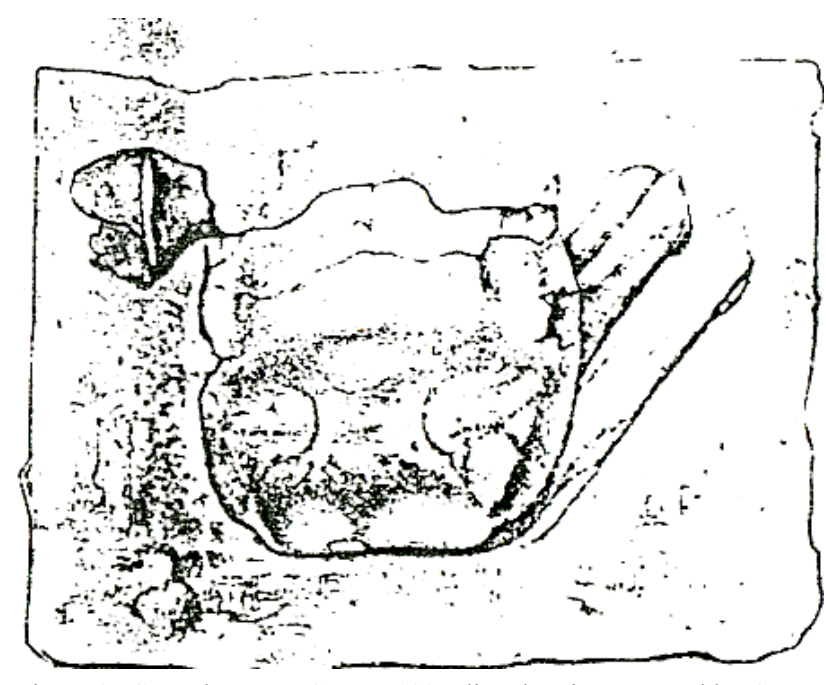

Figure 3. Goneplax sacci Crema, 1895, line drawing reported by Crema (1895: fig. 15). 
their identity might be decided only with well preserved topotypes in hand...". This observation supports the validity of $G$. gulderi as valid species.

Genus Albaidaplax n. gen.

Diagnosis: Carapace transversely rectangular, much wider than long; dorsal surface of carapace smooth with slight horizontal ridges, without clear indication of regions; straight front slightly turned downwards; wide orbits, gently expanded distally; supraorbital border gently sinuous; outer orbital angle with short acute tooth; anterolateral margins slightly convex, with single short tooth; male cheliped (P1) short, stout.

Etymology: from Albaida del Aljarafe, village nearby the quarry where the specimens were discovered.

Type species: Albaidaplax ispalensis n. sp. (gender feminine).

Description: as for the type species.

Discussion: The family Goneplacidae, as reported by Castro (2007: 616), has the following diagnostic characters: carapace transversely rectangular, subquadrate, or trapezoidal; front narrow to wide, typically lamellar, straight; dorsal surface smooth; varying number of anterolateral spines posterior to outer orbital angle (sometimes none but typically one or two); orbits moderately to conspicuously wide, long; fissure in supraorbital margin absent; dorsal surface of carapace typically smooth or with slight horizontal ridges, moderately convex, without clear indication of regions. Most of these characters are present in Albaidaplax n. gen., here assigned to Goneplacidae. Moreover, we justify the erection of the new fossil genus based on some additional morphological observations. The rectangular carapace and the anterolateral margins with single short tooth of Albaidaplax n. gen. excludes its belonging to Notonyx Milne-Edwards, A., 1873, or Pycnoplax Castro, 2007, both having quadrate carapace and anterolateral toothless margins or with two acute teeth respectively. The new genus does not belong to Carcinoplax. Milne Edwards, H., 1852, Eutricoplax Castro, 2007, or Menoplax Castro, 2007, which have rectangular carapace and anterolateral margins with two acute teeth. Albaidaplax n. gen. cannot be assigned to Hadroplax Castro, 2007, Paragoneplax Castro, 2007, Singhaplax Serène and Soh, 1976, Microgoneplax Castro, 2007, or Neommatocarcinus Takeda and Miyake, 1969, genera that present rectangular carapace and anterolateral margins toothless. Albaidaplax n. gen. does not belong to Ommatocarcinus White, 1852, which has rectangular carapace and straight front with a median notch. Finally, the new genus does not belong to Psopheticus Wood-Mason, 1892, Exopheticus Castro, 2007, or Pedroplax Ng and Komai, 2011, as these have subquadrate and subcircular carapaces and anterolateral margins with single short tooth, respectively.

Some morphological characters of Albaidaplax n. gen., such as the carapace transversely rectangular, much wider than long; orbits wide, gently expanded distally; supraorbital border gently sinuous; outer orbital angle with short acute tooth; and anterolateral margins slightly convex, with single short tooth, are also present in Thyraplax Castro, 2007, Goneplax Leach, 1814, Goneplacoides Castro, 2007, and Neogoneplax Castro, 2007. However, the new genus does not present certain characters that these genera do: Thyraplax present narrow orbits, not expanded distally; Goneplax has wide orbits, greatly expanded distally; and Neogoneplax present supraorbital borders conspicuously convex, while Albaidaplax n. gen. has wide orbits, gently expanded distally and supraorbital border gently sinuous. Goneplacoides, with the only extant species G. marivenae (Komatsu and Takeda, 2003), is the only extant genus sharing the above-mentioned morphological characters of the new fossil genus. However, it differs in the wide orbits expanded distally and strongly inclined distally (almost straight in Albaidaplax n. gen.), the much reduced anterolateral margins (longer in Albaidaplax n. gen.), and the straight posterolateral margins strongly converging to the posterior margin (gently rounded in Albaidaplax n. gen.).

According to Karasawa and Kato (2003) and Schweitzer et al. (2010) the Goneplacidae includes eight fossil genera: Amydrocarcinus Schweitzer, Feldmann, González-Barba and Vega, 2002; Carcinoplax Milne Edwards, H., 1852; Goneplax Leach, 1814; Icriocarcinus Bishop, 1988; Kowaicarcinus Feldmann, Schweitzer, Maxwell and Kelley, 2008; Magyarcarcinus Schweitzer and Karasawa, 2004; Ommatocarcinus White, 1852; and Psopheticus WoodMason, 1892. Carcinoplax, Goneplax, Psopheticus, and Ommatocarcinus are extant genera from which Albaidaplax n. gen. is excluded (see discussion above). Amydrocarcinus was described from the Eocene Tepetate Fm. (Mexico) (Schweitzer et al., 2002; Schweitzer and Karasawa, 2004), Icriocarcinus from the Late Cretaceous (late Campanian or early Maastrichtian) of San Diego County (California, USA) (Bishop, 1988), Kowaicarcinus from the Pliocene of New Zealand (Feldmann et al., 2008), and Magyarcarcinus from the Late Eocene of Hungary (Schweitzer and Karasawa, 2004). We exclude Albaidaplax n. gen. from these genera not only for geological and paleogeographic implications, but also for the ovoid carapace, small and squared orbits of Amydrocarcinus; the pentagonal carapace, anterolateral margins with three acute spines, and the dorsal surface of the carapace strongly ridged of Icriocarcinus; the hexagonal carapace, small and ovoid orbits, and tri-lobed anterolateral margin of Kowaicarcinus; and the circular carapace, small and ovoid orbits of Magyarcarcinus.

\section{Albaidaplax ispalensis n. sp.} Figure 4

\section{2 (5).}

Goneplax gulderi-Mayoral et al., 1998: 508, 509, fig.

Goneplax cf. saccoi [sic] - Vía, 1948: 146, fig. 6. - Solé and Vía, 1989: 34. 
Diagnosis: Carapace transversely rectangular, slightly wider than long; smooth dorsal surface of carapace, with slight horizontal ridges, moderately convex, without clear indication of regions; straight front slightly turned downwards; front as wide as the orbits; inner edge of supraorbital margin distinct; wide orbits, gently expanded distally; supraorbital border gently sinuous; outer orbital angle with short acute tooth; anterolateral margins slightly convex, with single short tooth; posterolateral margins gently rounded, slightly converging posteriorly; long, straight posterior margin, slightly convex medially; male cheliped (P1) equal, short, with stout palm.

Etymology: from Ispal, name of an ancient village nearby Sevilla, city located close to the quarry where the specimens were discovered.

Holotype: MGUS AA5.

Paratypes: MGUS AA2, AA3, AA4, AA6, AA45.

Type locality: Albaida del Aljarafe (Guadalquivir Basin, Seville, Andalusia, Spain).

Geological age: Early Pliocene - Early Pleistocene.

Additional studied material: MGUS AA7-AA27, AA29-AA40, AA42-AA44, AA46, AA47, AA49, AA50; GPDG 0194.

Additional material: MSNM i27830, i27831, i27832 (Monterotondo Marittimo, Grosseto, Tuscany): Pliocene sensu lato; MSNM i27833 (Volterra, Pisa, Tuscany): Early Pliocene (Zanclean); MUSNAF 7074 (Poggio i Sodi, Castelnuovo Berardenga-Scalo, Siena, Tuscany): Early Pleistocene.

Remark: Garassino et al. (2012) ascribed one specimen (GPDG 0194) from the Early Pliocene (Zanclean) of La Serra quarry (San Miniato, Pisa, Tuscany) to Goneplax sacci. However, its rectangular carapace, slightly wider than long and the wide orbits, gently expanded distally excludes its belonging both to Goneplax, which has rectangular carapace strongly wider than long and wide orbits, conspicuously expanded distally, and to G. sacci, here considered as species nomen dubium. The rectangular carapace, slightly wider than long and the wide orbits, slightly expanded distally allow to assign this specimen to A. ispalensis $\mathrm{n}$. sp.

Description: Carapace transversely rectangular, slightly wider than long; straight front slightly turned downwards; front as wide as the orbits; inner edge of supraorbital margin distinct; wide orbits slightly expanded distally with one short tooth on outer orbital angle; supraorbital margins gently sinuous, without fissures; sinuous, spineless suborbital margins; anterolateral margins slightly convex, with one short tooth; long, gently rounded posterolateral margins, slightly converging posteriorly; long, straight posterior margin; deep gastric pits; smooth dorsal surface of carapace; slight horizontal ridges, moderately convex, without clear indication of regions; stout, heavy chelipeds (P1), with moderately long merus; subtriangular, spineless carpus; stout, globular palm; dactylus and index slender, as long as the propodus, with toothless occlusal margin; smooth surface of chelipeds; ambulatory legs (P2-P5) conspicuously long, slender, smooth.

Discussion: Mayoral et al. (1998) assigned a rich sample of goneplacids from the Early Pliocene of Guadalquivir Basin (Sevilla, Spain) to Goneplax gulderi. This species was also reported by some authors in different areas of Spain: Vía (1948) reported one specimen from the Miocene of Montjuich (Barcelona) (Villalta coll.) today lost (Gallemi, pers. comm., 2012); although the specimen was assigned to Goneplax cf. saccoi [sic] by Vía (1948) and Solé and Vía (1989), Müller (1993) ascribed it to G. gulderi; Müller (1993) assigned two specimens from the Early Pliocene of St. Feliu de Llobregat (Barcelona, ARES coll.) and Sant Vicenç dels Horts (Barcelona, Viader coll.) to Goneplax gulderi, without repositories. Based on these observations, the only available Spanish sample is that from the Guadalquivir Basin. The review of this rich collection has pointed out that these specimens cannot belong to Goneplax, which has rectangular carapace, slightly wider than long, and wide orbits, gently expanded distally, characters not diagnostic of Albaidaplax (Castro, 2007). So the Spanish specimens are assigned to $A$. ispalensis $\mathrm{n}$. $\mathrm{sp}$. (see discussion of the genus).

\section{Genus Neogoneplax Castro, 2007}

Type species: Neogoneplax renoculis Rathbun, 1914, by subsequent designation of Castro (2007).

Diagnosis (after Castro, 2007): Carapace transversely rectangular, much wider than long; widest at conspicuous outer orbital teeth; front slightly deflected ventrally, sinuous, marked by two slight emarginations, small to minute median projection between emarginations. Slight notch between front, inner edge of supraorbital border; orbits wide, greatly expanded distally; supraorbital borders conspicuously convex; suborbital borders convex, with one or two slight, obtuse inner teeth not visible dorsally; anterolateral borders short, straight. Dorsal surface of the carapace smooth or with slight horizontal ridges, moderately convex, without clear indication of regions. Outer orbital angle with conspicuous, acute tooth; acute anterolateral tooth on each side of the carapace (much reduced in N. costata Castro, 2007). Basal antennal article short, distalmost (third) article nearly reaches front. Eye peduncles long, shorter than or longer than front (0.8-1.1 front width); cornea strongly reniform, dorso-ventrally flattened, nearly divided into anterior and posterior portions. Anterior border of endostome well demarcated from buccal cavern, ridges faint but clearly defined. Third maxillipeds nearly completely close the buccal cavern. No obvious stridulating mechanism other than possible rubbing of proximal portion of cheliped (P1) merus against pterygostomial ridge. Wide thoracic sternum. Median sulcus on thoracic sternite 4 absent; sutures $4 / 5$, $5 / 6,7 / 8$ interrupted medially, 6/7 complete. Anterior end of sterno-abdominal cavity anterior to thoracic sternite 4 . Cheliped fingers long, slender, shovel-like, curved, pollex 

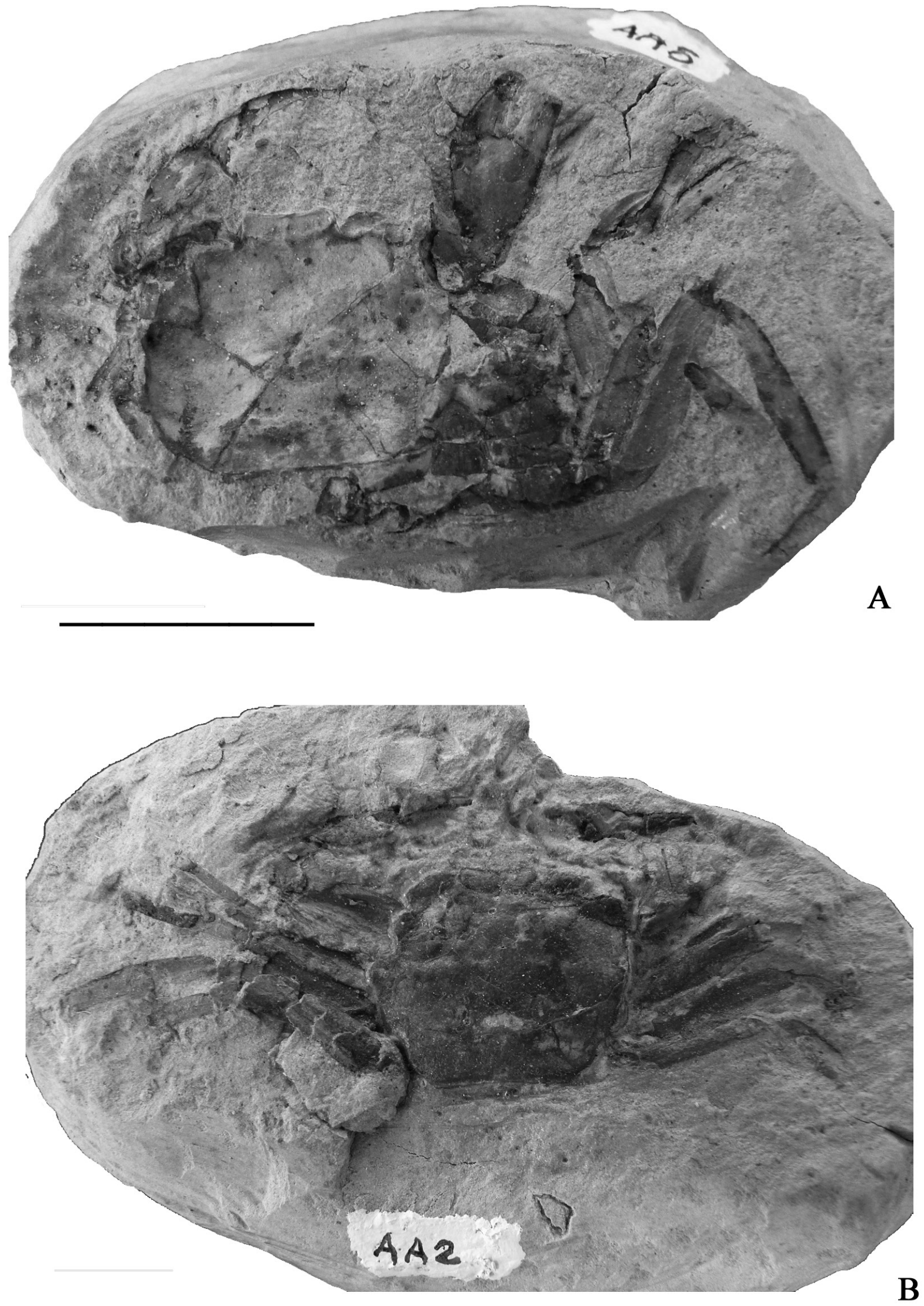

Figure 4. Albaidaplax ispalensis n. sp. A) holotype AA5. B) paratype AA2. Scale bar: $10 \mathrm{~mm}$. 
higher than dactylus in large individuals, shorter than elongated propodus; dactylus light in colour, without dark portion; carpus with conspicuous tooth on inner margin. Dorsal margins of ambulatory leg (P2-P5) meri unarmed, or with acute distal tooth or with several teeth; dactyli slender, with carina on each side, non-setose. Male pleon with 6 freely-movable somites plus telson, wide, somites 4-6 gradually decreasing in width from somite 3 (widest somite). Telson wide, clearly longer than wide. Somite 3 covers space between P5 coxae, somite 2 narrower than somite 3; somites 1, 2 leave small to large portion of thoracic sternite 8 visible. G1 varies from long, slender, slightly sinuous, slightly broadened proximally to stout, short, with obtuse tip. G2 slender, slightly shorter to slightly longer than G1, flagellum slightly longer than proximal part (peduncle), tip curved or straight, pointed. Penis arising from P5 coxa, moderate size; broad, soft proximal expansion. Female pleon with 6 freely-movable somites, wide. Telson much wider than long. Somite 3 covers space between P5 coxae, somite 2 slightly narrower than somite 3 ; somites 1,2 leave small portion of thoracic sternite 8 visible. Vulva of mature females small, oval, extending from $5 / 6$ suture to median portion of thoracic sternite 6 , vulvar cover present.

\section{Neogoneplax arenicola (Glaessner, 1960)} Figure 5

Ommatocarcinus arenicola Glaessner, 1960: 28-30, fig. 12b, pl. 7, fig. 3 .

Ommatocarcinus arenicola - Takeda and Miyake, 1969: 175. - Jenkins, 1975: 34, 35, 48, 57, fig. 4b. - Feldmann, 1992: 11, 21.
Goneplax arenicola - Karasawa and Kato, 2003: Tab. 6. - Feldmann et al., 2006: 422. - Castro, 2007: 686. Schweitzer et al., 2010: 135.

Emended diagnosis: Carapace transversely trapezoidal, slightly wider than long, widest at anterolateral obsolete tooth; carapace smooth, with two slight horizontal ridges, without clear indication of regions; straight front slightly turned downwards; front shorter than the orbits; wide orbits, greatly expanded distally; outer orbital angle with conspicuous acute tooth; anterolateral margins slightly diverging frontally; single obsolete anterolateral tooth; male cheliped (P1) well developed, with elongated palm (after Glaessner, 1960).

Holotype: GNS AR 155 (A. McKay coll.).

Geological age: Late Oligocene - Middle Miocene.

Occurrence: South Island of New Zealand (Mt. Brown, Waipara River).

Description: Glaessner (1960) gave a detailed description of the species here confirmed. The only remark is that the front median notch reported by the author, is not a diagnostic character, but only the imprint of an internal subrostral thickening structure, as already revealed in other reviewed specimens from Spain and Italy lacking the original exoskeleton.

Discussion: Glaessner (1960: 29) described Ommatocarcinus arenicola from the Late Oligocene Middle Miocene of New Zealand, pointing out that "...The new species is closer in the shape of its carapace to the less specialised genus Goneplax Leach, but the front is more like that of Ommatocarcinus, to which the species is assigned as an early primitive form...". Later Takeda and Miyake (1969: 175 ) proposed a new goneplacid genus, pointing out “...

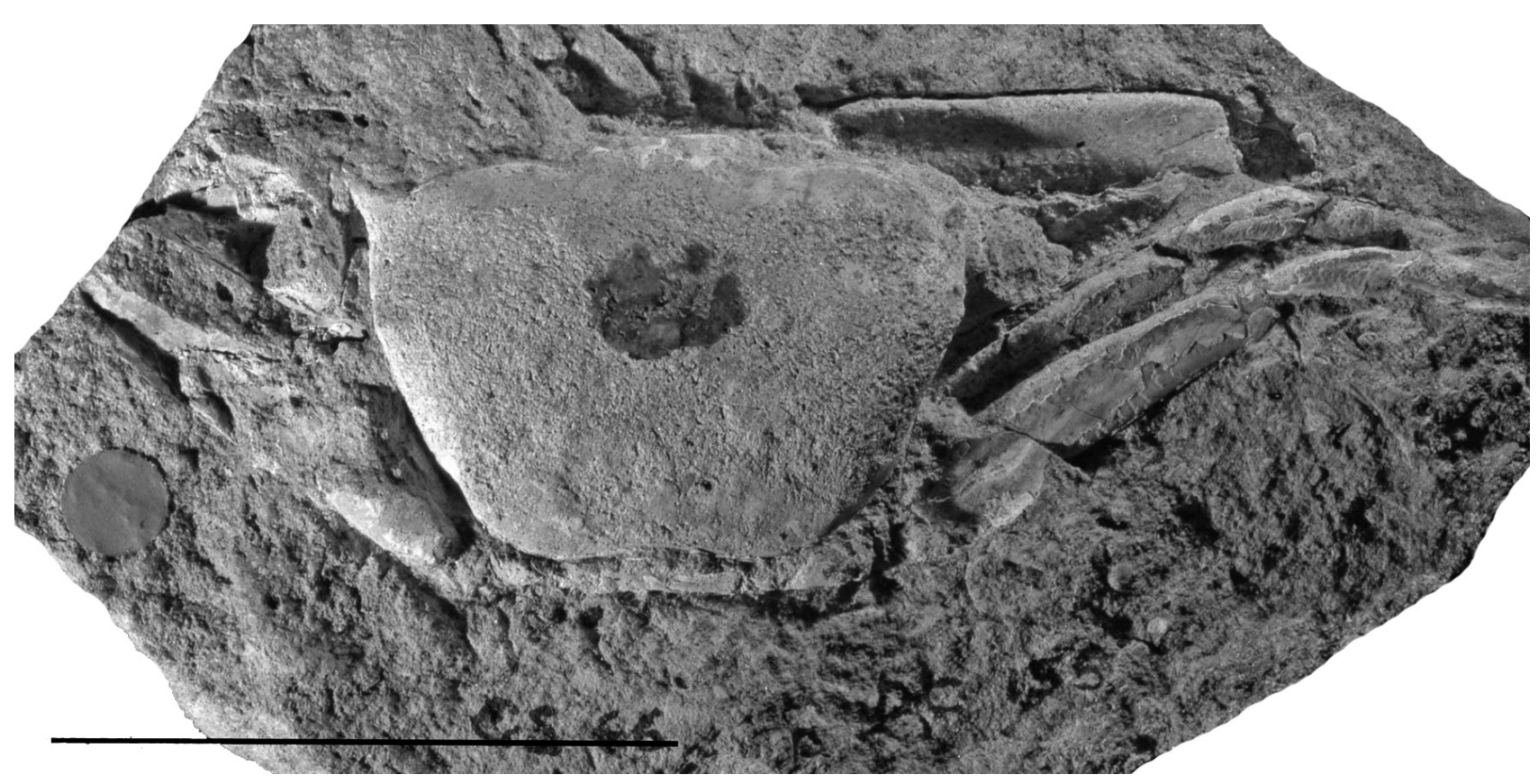

Figure 5. Neogoneplax arenicola (Glaessner, 1960), holotype GNS AR 155. Scale bar: 32 mm. 
Though the specimen may be possibly assigned to an early primitive form of the genus Ommatocarcinus, it is impossible to be retained in the genus, and represents a distinct genus due to bearing the quite different contour of the carapace that is less specialized somewhat like that of the genus Goneplax Leach, 1814. The new generic name, Glaessneria, is therefore proposed for a fossil species Ommatocarcinus arenicola Glaessner, 1960 ...”. Although Glaessner (1960) and Jenkins (1975) reported that Ommatocarcinus arenicola has a straight front, marked by slight median notch, we point out that this cannot be considered as a diagnostic character, but only an artificial impression due to the taphonomy process, as remarked for other fossil specimens reviewed from Spain and Italy. Karasawa and Kato (2003) did not agree with the assignment of $O$. arenicola to a proposed new genus by Takeda and Miyake (1969), pointing out that "The carapace in this species bears two anterolateral teeth with an anterolaterally directed outerorbital tooth, has a relatively wide front without a median projection, and lacks a distinct transverse ridge dorsally; therefore the species is here moved to Goneplax". However, the review of the type specimen of $O$. arenicola has pointed out that this species cannot be assigned to Goneplax, as proposed by Karasawa and Kato (2003), because of certain characters, not diagnostic for this genus, such as the carapace transversely trapezoidal, slightly wider than long; wide orbits, greatly expanded distally; supraorbital border conspicuously convex; outer orbital angle with conspicuous acute tooth; anterolateral margins slightly diverging frontally; and single obsolete anterolateral tooth (Castro, 2007). Moreover, arenicola cannot be assigned to Ommatocarcinus for the lack of the front median notch, even though it shares the carapace transversely rectangular, wider than long and one anterolateral tooth with two extant genera, Thyraplax and Goneplacoides. However, the wide orbits, conspicuously expanded distally and the supraorbital border conspicuously convex of arenicola exclude its assignment both to Thyraplax (orbits narrow, not expanded distally) and to Goneplacoides (supraorbital border conspicuously sinuous). Finally, arenicola shares its main morphological characters, such as the carapace transversely rectangular, wider than long; wide orbits, conspicuously expanded distally; and the supraorbital border conspicuously convex with the extant Neogoneplax to which is assigned. Indeed, arenicola shares these characters mainly with the extant N. costata (Castro, 2007: fig. 30) from Philippine Islands, which presents carapace transversely rectangular, wider than long, supraorbital border conspicuously convex, and reduced anterolateral tooth, appearing as slight prominence.

\section{Conclusion}

This revision attests that Goneplax, with G. rhomboides and G. gulderi, is restricted to the Mediterranean area, from the Miocene to Recent. Albaidaplax appears to be restricted to the Mediterranean area during the Pliocene -Pleistocene. The assignment of arenicola to Neogoneplax attests the restricted geographic distribution of this genus in the Eastern Pacific Ocean.

\section{Acknowledgments}

We wish to thank S. Dominici (Museo di Geologia e Paleontologia, Università degli Studi, Firenze) for the photographs of the holotype and syntypes of $G$. formosa and G. meneghinii; J. Gallemi (Museu de Ciéncies Naturals de Barcelona, Spain) provided information about Vía’s specimens; H. Karasawa (Mizunami Fossil Musem, Japan) provided references about the fossil species of Goneplax; A. Kroh (Natural History Museum, Wien) for the photographs of the holotype of G. gulderi; Mayoral Alfaro (Departamento de Geología, Universidad de Huelva, Spain) for the photographs of G. gulderi from Spain; M. Neri (Museo di Vignola) and P. Serventi (Dipartimento di Geologia, Università di Modena e Reggio Emilia) provided information about the specimens of $G$. meneghinii deposited in the Museo Geologico di Modena; D. Ormezzano (Museo Regionale di Scienze Naturali, Torino) for information about the holotype of G. sacci; J. Simes (Collection Manager, GNS Science, New Zealand) for the photographs of the holotype of G. arenicola; D. Guinot (Département Milieux et peuplements aquatiques, Muséum national d'Histoire naturelle, Paris) and F. J. Vega (Instituto de Geología, Universidad Nacional Autónoma de México, Ciudad Universitaria, Coyoacán, México) for careful review and criticism.

\section{References}

Bachmayer, F., 1953, Goneplax gulderi, eine neue Crustaceen-Species aus dem tortonischen Tegel des Wiener-Beckens: Paläontologische Zeitschrift, 27(3-4), 143-145.

Beschin, C., Busulini, A., De Angeli, A., Tessier, G., 1996, Retroplumoidea (Crustacea, Brachyura) nel Terziario del Vicentino (Italia settentrionale): Società Veneziana di Scienze Naturali, 21, 83-102.

Bishop, G. A., 1988, Two crabs, Xandaros sternbergi (Rathbun, 1926) n. gen., and Icriocarcinus xestos n. gen., n. sp., from the late Cretaceous of San Diego County, California, USA, and Baja California Norte, Mexico: Transactions of the San Diego Society of Natural History, 21(15), 245-257.

Bouvier, E.-L., 1940, Décapodes marcheurs, in Faune de France, 37, 1-404.

Capezzuto, F., Carlucci, R., Maiorano, P., Sion, L., Battista, D., Giove, A., Indennidate, A., Tursi, A., D’Onghia, G., 2010, The bathyal benthopelagic fauna in the north-western Ionian Sea: structure, patterns and interactions: Chemistry and Ecology, 26, 199-217.

Castro, P., 2007, A reappraisal of the family Goneplacidae MacLeay, 1838 (Crustacea, Decapoda, Brachyura) and revision of the subfamily Goneplacinae, with the description of 10 new genera and 18 new species: Zoosystema, 29(4), 609-774.

Castro, P., Guinot, D., Ng., P.K.L., 2010, A new family for Sotoplax robertsi Guinot, 1984, with a key to the Goneplacoidea (Crustacea: Decapoda: Brachyura): Zootaxa, 2356, 36-56. 
Celik, E.S., Ates A.S., Akbulut M., 2007, A Survey on the Brachyura (Crustacea, Decapoda) in the Dardanelles: Turkish Journal of Zoology, 31, 181-183.

Company, J.B., Maiorano, P., Tselespides, A., Politou, C.-Y., Plaity, W., Rotllant, G., Sardá, F., 2004, Deep-sea decapod crustaceans in the western and central Mediterranean Sea: preliminary aspects of species distribution, biomass and population structure: Scientia Marina, 68(3), 73-86.

Crema, C., 1895, Sopra alcuni decapodi fossili terziari del Piemonte: Atti della Reale Accademia di Scienze di Torino, 30(13), 664-681.

De Angeli, A., Garassino, A., 2006, Catalog and bibliography of fossil stomatopoda and decapoda from Italy: Memorie della Società italiana di Scienze naturali e del Museo civico di Storia naturale di Milano, 35(1), 3-96.

De Angeli, A., Garassino, A., Pasini, G., 2009, New reports of anomurans and brachyurans from the Cenozoic of Tuscany (Italy): Atti della Società italiana di Scienze naturali e del Museo civico di Storia naturale in Milano, 150(2), 163-196.

De Angeli, A., Garassino, A., Pasini, G., 2011, Retropluma craverii (Crema, 1895) (Crustacea, Decapoda, Brachyura, Retroplumidae) from the Pliocene of Reggio Emilia (N Italy): Atti della Società italiana di Scienze naturali e del Museo civico di Storia naturale in Milano, 152(1), 37-44.

Desmarest, A.G., 1817, Crustacés fossiles, in Société de Naturalistes et d'Agriculteurs (Ed.), Nouveau Dictionnaire d'Histoire naturelle, appliquée aux Arts, à l'Agriculture, à l'Économie rurale et domestique, à la Médecine, etc, Vol. 7 [COR-CUN]: Déterville, Paris, 495-519.

Desmarest, A.G., 1822. Les crustacés proprement dits, in Brongniart, A., Desmarest, A.G. (Eds.), Histoire naturelle des crustacés fossiles sous les rapports zoologiques et géologiques: F.G. Levrault, Libraire, Paris, 67-142.

D'Udekem d'Acoz, C. 2001, New records of Monodaeus couchii (Couch, 1851 ) and Goneplax rhomboides (Linnaeus, 1758) in the North Sea (Crustacea, Decapoda, Brachyura): De Strandvlo, 21(2), 48-50.

Falciai, L., Minervini, R., 1992, Guida dei Crostacei Decapodi d'Europa: Muzzio Ed., 272 pp.

Fanelli, E., Colloca, F., Ardizzone, G., 2007, Decapod crustacean assemblages of the West coast of central Italy (western Mediterranean): Scientia Marina, 71(1), 19-28.

Feldmann, R.M., 1992, Systematic and stratigraphic review with catalogue and locality index of the Mesozoic and Cenozoic decapod crustacea of New Zealand: New Zealand Geological Survey, 45, 1-71.

Feldmann, R.M., Schweitzer, C.E., McLauchlan, D., 2006, Additions to the records for decapod Crustacea from Motunau and Glenafric Beaches, North Canterbury, New Zealand: New Zealand Journal of Geology \& Geophysics, 49, 417-427.

Feldmann, R. M., Schweitzer, C. E., Maxwell, P. A., Kelley B. M., 2008, Fossil isopod and decapod crustaceans from the Kowai Formation (Pliocene) near Makikihi, South Canterbury, NewZealand: New Zealand Journal of Geology and Geophysics, 51, 43-58.

Garassino, A., De Angeli, A., 2004, Decapod crustacean fauna from the Pliocene and Pleistocene of Arda, Stirone and Enza Rivers (Piacenza, Parma and Reggio Emilia Provinces, N Italy): Atti della Società italiana di Scienze naturali e del Museo civico di Storia naturale in Milano, 145(1), 29-57.

Garassino, A., De Angeli, A., Gallo, L. M., Pasini, G., 2004, Brachyuran and anomuran fauna from the Cenozoic of Piemonte (NW Italy): Atti della Società italiana di Scienze naturali e del Museo civico di Storia naturale in Milano, 145(2), 251-281.

Garassino, A., Pasini, G., De Angeli, A., Charbonnier, S., Famiani, F., Baldanza, A., Bizzarri, R., 2012, The decapod community from the Early Pliocene (Zanclean) of "La Serra" quarry (San Miniato, central Italy): sedimentology, systematics, and palaeoenvironmental implications: Annales de Paléontologie, 98, 1-61.

Garcia Raso, J.E., 1984, Brachyura of the coast of Southern Spain: Spixiana, 7(2), 105-113.

Garcia Socias, Ll., Massuti Jaume, C., 1987, Inventari bibliographic dels
Crustacis Decàpodes de les Balears (Crustacea, Decapoda): Bolleti de la Societat d'Historia Natural de les Balears, 31, 67-92.

Gemmellaro, M., 1914, Crostacei e pesci fossili del "Piano Siciliano" dei dintorni di Palermo: Giornale di Scienze Naturali ed Economiche di Palermo, 30, 73-94.

Gill, T., 1894, A new bassalian type of crabs: American Naturalist, 28, 1043-1045.

Glaessner, M.F., 1928, Die Dekapodenfauna des österreichischen Jungtertiärs: Jahrbuch der Geologischen Bundesanstalt, 78, 161-218.

Glaessner, M.F., 1929, Crustacea Decapoda, in Pompeckj, F.J. (ed.), Fossilium Catalogus. I: Animalia, 41, 1-464.

Glaessner, M.F., 1960, The fossil decapod Crustacea of New Zealand and the evolution of the order Decapoda: New Zealand Geological Survey Palaeontological Bulletin, 31, 1-63.

Guinot, D., Castro, P., 2007, A new species of Goneplax Leach, 1814 (Crustacea, Decapoda, Brachyura, Goneplacidae) from the south Atlantic and the western limits of the Indo-West Pacific region, long confused with G. rhomboides (Linnaeus, 1758): Zootaxa, $1577,17-31$.

Heller, C., 1863, Die Crustaceen des südlichen Europa, Crustacea Podophthalmia. Mit einer Übersicht über die horizontale Verbreitung sämtlicher europäischer Arten: Wilhelm Braumüller, Wien, 336 pp.

Holthuis, L.B., Gottlieb, E., 1958, An annotated List of the Decapod Crustacea of the Mediterranean Coast of Israel, with an Appendix listing the Decapoda of the eastern Mediterranean: Bulletin of the Research Council of Israel, 7B, 1-126.

Holthuis, L.B., 1961, Report on a collection of Crustacea Decapoda and Stomatopoda from Turkey and the Balkans: Zoologische Verhandelingen, 47, 1-67.

Jenkins, R. J. F., 1975, The fossil crab Ommatocarcinus corioensis (Cresswell) and a review of related Australian species: Memories of the Natural Museum of Victoria, 36, 33-62.

Karasawa, H., Kato, H., 2003, The family Goneplacidae MacLeay, 1838 (Crustacea: Decapoda: Brachyura): systematics, phylogeny, and fossil records. Paleontological Research, 7(2), 129-151.

Komatsu, H., Takeda, M., 2003, Two new species of the genus Goneplax (Decapoda, Brachyura, Goneplacidae) from East Asia: Crustaceana, 76, 1243-1256.

Lamarck, J.B.P.A., 1801, Systéme des animaux sans vertebras ou Tableau general des classes, des orders et des genres de ces animaux; Présentant leurs caractères essentials et leur distribution, d'après la considération de leurs rapports naturles et de leur organisation, et suivant l'arrangement établi dasn les galleries du Muséum d'Hist. Naturelle, parmi leurs dépouilles conserves; Précédé du discours d'ouverture du Cours de Zoologie donné dans le Muséum National d'Histoire Naturelle l'an 8 de la République: Paris.

Leach, W.E., 1814, Crustaceology, in Brewster, D., The Edinburgh Encyclopedia, 7, 383-437.

Linnaeus, C., 1758, Systema Naturae per Regna Tria Naturae, Secundum Classes, Ordines, Genera, Species, cum Characteribus, Differentiis, Synonymis, Locis. 10(1), 1-824.

Lőrenthey, I., 1907, Palaeontologiai tanulmányok a harmadkorú rákok körébol VI, Adatok Sardinia Harmadidoszakbeli rák faunájához: Mathematikai és Természettudományi Közlemények, 29(2), 243295.

Lörenthey, I., 1909, Beiträge zur Tertiären Dekapodenfauna Sardiniens: Mathematische und Naturwissenschaftlichen Berichte aus Ungarn, $24,202-259$.

MacLeay, W.S., 1838, On the Brachyurous Decapod Crustacea. Brought of the Zoology of South Africa; consisting chiefly of figures and descriptions of the objects of natural history collected during an expedition into the interior of South Africa, in the years 1834, 1835, and 1836; fitted out by "The Cape of Good Hope Association for Exploring Central Africa": together with a summary of African Zoology, and an inquiry into the geographical ranges of species in that quarter of the globe: Smith, Elder \& Co., London., published under the Authority of the Lords Commissioners of Her Majesty's Treasury, Invertebratae, IV (1849), 53-71 
Mayoral, E., Müller, P., Muñiz, F., 1998, Lower Pliocene decapod crustaceans from the southwestern Iberian Peninsula (Guadalquivir Basin, Sevilla, Spain): Geobios, 31(4), 505-510.

Milne-Edwards, A., 1861, Faune carcinologique des terrains quaternaires. L'Institut: Journal universel des Sciences et des Societés savantes en France et à l'étranger, 29, 88.

Milne-Edwards, A., 1873, Groupe des cyclometopes, Portuniens: Recherches sur la faune carcinologique de la Nouvelle-Calédonie, deuxième partie: Nouvelles Archives du Muséum d'Histoire naturelle de Paris, 9, 155-352.

Milne Edwards, H., 1852, Observations sur les affinities zoologiques et la classification naturelle des crustacés: Annales des Sciences naturelles, Zoologie, ser. 3(18), 109-166.

Müller P., 1979, Crustacés décapodes du Badénien et Sarmatien de Bulgarie: Paleontology, Stratigraphy and Lithology, 10, 3-7.

Müller, P., 1984, Decapod Crustacea of the Badenian: Geologica Hungarica, series palaeontologica, 42, 1-117.

Müller, P., 1993, Neogene Decapod Crustaceans from Catalonia: Scripta Museum Seminario Barcinonensis, 225, 1-39.

Müller, P., 1998, Catalogus Fossilium Austriae: Verlag der Österreichischien Akademie der Wissenschaften, 7(2b), 5-46.

Mura, M. Corda S., 2011, Crustacea Decapoda in the Sardianian channel: a checklist: Crustaceana, 84(5-6), 667-687.

Neumann, H., Ehrich, S., Kröncke, I., 2010, Establishement of the angular crab Goneplax rhomboides (Linnaeus, 1758) (Crustacea, Decapoda, Brachyura) in the southern North Sea: Aquatic Invasions, 5(1), S27-S30.

Ng, P.K.L., Guinot, D., Davie, P.J.F., 2008, Systema Brachyurorum: Part I., An annotated checklist of extant brachyuran crabs of the world: The Raffles Bulletin of Zoology, supplement 17, 3-276.

Ng., P.K.L., Komai T., 2011, A new genus for Psopheticus megalops Takeda, 1989 (Crustacea: Brachyura: Goneplacidae): Zootaxa, 2934, 61-67.

Nobre, A., 1936, Crustáceos Decápodos e Stomatópodes Marinhos de Portugal, in Fauna Marinha de Portugal, 4, 1-213.

Pasini, G. Garassino, A., 2013, Records of brachyuran crabs from the Pliocene (Piacenzian) of Reggio Emilia (Emilia Romagna, N Italy): Boletín de la Sociedada Geologica Mexicana, 65(2), 319-328.

Pastore, M.A., 1972, Decapoda crustacea in the Gulf of Taranto and the Gulf of Catania with a discussion of a new species of Dromidae (Decapoda Brachyoura) in the Mediterranean Sea: Thalassia Jugoslavica, 8(1), 105-117.

Rathbun, M.J., 1914, A new genus and some new species of crabs of the family Goneplacidae, Scientific Results of the Philippine cruise of the Fisheries Steamer "Albatross", 1907-1910-No. 32: Proceedings of the United States National Museum, 48(2067), 137-154.

Rice, A.L. Chapman, C.J., 1971, Observations on the burrows behaviour of two mud-dwelling decapod crustaceans, Nephrops norvegicus and Goneplax rhomboides: Marine Biology, 10, 330-342.

Ristori, G., 1886, I crostacei brachiuri e anomuri del Pliocene italiano: Bollettino della Società Geolologica Italiana, 5, 93-129.

Ristori, G., 1891, I crostacei fossili di Monte Mario: Atti delle Società Toscana di Scienze Naturali, Memorie, 11, 19-25.

Ristori, G., 1892, Note di Carcinologia pliocenica: Atti della Società Toscana di Scienze Naturali, processi verbali, 8, 86-89.

Ristori, G., 1896, Crostacei neogenici di Sardegna e di alcune altre località italiane: Bollettino della Società Geologica Italiana, 15, 504-513.

Schweitzer, C.E., Feldmann, R.M., Garassino, A., Karasawa, H., Schweigert, G., 2010, Systematic list of fossil decapod crustacean species: Crustaceana Monographs, 10, 1-222.
Schweitzer, C.E., Feldmann, R.M., Gonzáles-Barba, G., Vega F.J., 2002, New crabs from the Eocene and Oligocene of Baja California Sur, Mexico and an assessment of the evolutionary and paleobiogeographic implications of Mexican fossil decapods: Journal of Paleontology, memoir 59, 76(6), 1-43.

Schweitzer, C. E., Karasawa H., 2004, Revision of Amydrocarcinus and Palaeograpsus (Decapoda: Brachyura: Xanthoidea) with definition of three new genera: Paleontological Research, 8(1), 71-86.

Serène, R., Soh, C.L., 1976, Brachyura collected during the Thai-Danish Expedition (1966): Research Bulletin Phuket Marine Biological Center, 12, 1-37.

Solé, J., Vía, L., 1989, Crustacis Decàpodes fòssils dels Països Catalans: Batalleria, 2, 23-42.

Suat Ates, A., Katagan, T., Kocatas, A., 2006, Bathymetric distribution of decapod crustaceans on the continental shelf along the Aegean coasts of Turkey: Crustaceana, 79(2), 129-141.

Takeda, M., Miyake, S., 1969, A small collection of crabs from New Zealand: OHMU (Occasional Papers of Zoological Laboratory, Faculty of Agriculture, Kyushu University), 2, 157-193.

Tettoni, W., 1924, Crostacei pliocenici dell'Appennino Modenese: Atti della Società dei Naturalisti e Matematici di Modena, ser. 6, 1 and 2 (53 and 54), 160-162.

Vía Boada, L., 1933, Catàleg systematic dels crustacis dels suborders "Decapoda" i "Stomatopoda" existents en el Museu d'Historia Natural del Seminari de Barcelona: Butlleti de la Institució Catalana d'Història Natural, 33(4-6), 223-226.

Vía, L., 1948, Braquiuros fósiles de Barcelona y sus alrededores: Anales de la Escuela de Peritos Agricolas y de Servicios Técnicos de Agricultura, 7, 143-152.

Vukanic, V., 2003, Contribution to diversity of crustaceans in the Adriatic: Natura Montenegrina, 2, 139-154.

White, A., 1852, Descriptions of some apparently new species of Annulosa (collected by Mr. Macgillvray during the voyage of H.M.S. Rattlesnake). Appendix no. 6, in MacGillivray J., Narrative of the voyage of H.M.S. Rattkesnake, commanded by the late Captain Owen Stanley, R.N., F.R.S. etc. during the years 1846-1850, Including discoveries and surveys in New Guinea, the Louisiade Archipelago, etc. to which is added the account of Mr. E.B. Kennedy's expedition for the exploration of the Cape York Peninsula, 2, 387-395.

Wood-Mason, J., 1892, Illustrations of the Zoology of the Royal Indian marine Surveying Steamer Investigator, Under the Command of Commander A. Carpenter R.N., D.S.O. and Commander R.F. Hoskyn, R.N: Crustacea, Part 1, Office of the Superintendent of Government Printing, Calcutta.

Zariquiey Álvarez, R., 1946, Crustáceos Decápodos Mediterráneos: Instituto Español de l'est Mediterráneo, Barcelona, 181 pp.

Zariquiey Álvarez, R., 1959, Crustáceos Decápodos de la region de Cadaqués. Parte II: Miscelanea zoologica Museo Zoologico Barcelona, 1(2), 1-7.

Zariquiey Álvarez, R., 1968, Crustáceos Decápodos Ibéricos: Investigacíon Pesquera, Barcelona, 32, 1-499.

Manuscript received: September 20, 2012.

Corrected manuscript received: November 19, 2012.

Manuscript accepted: November 20, 2012. 